\title{
A Multi-Level Evaluation of Policy Integration of Human Resource Development in Agriculture Sector
}

\author{
Ranjan Roy ${ }^{1,2 *}$, Ngai Weng Chan ${ }^{1}$ \\ ${ }^{1}$ School of Humanities, Universiti Sains Malaysia, Penang, Malaysia \\ ${ }^{2}$ Faculty of Agriculture, Sher-e-Bangla Agricultural University, Dhaka, Bangladesh \\ Email: ranjansau@yahoo.com
}

Received 19 December 2013; revised 22 January 2014; accepted 6 February 2014

Copyright (C) 2014 by authors and Scientific Research Publishing Inc.

This work is licensed under the Creative Commons Attribution International License (CC BY). http://creativecommons.org/licenses/by/4.0/

(c) (i) Open Access

\begin{abstract}
Human resource development assumes as a golden key for a knowledge-based economy and competitiveness. This study evaluates policy integration of human resource development (HRD) in agricultural sector within the context of multi-level governance (i.e., interdependence of administrative levels in decision making) and suggests means to enhance policy integration in Bangladesh. Conducting a critical review of major policy instruments, key informant interview and two case studies, this study concluded that HRD issue has fairly included and observed consistency (between the aim of HRD and policy) in all policies and strategies; majority of policy instruments have significantly addressed the significance of HRD and added plans for its development; reporting, monitoring and evaluation of policies and strategies are rather weak and there is no adequate flow of financial arrangement that is largely determined by the availability of government project. Based on the findings, the following means should be useful for improving HRD policy integration such as providing a handsome amount of development budget at the sub-district agricultural office, formulating coherent strategies to build effective cooperation, coordination and participation among stakeholders, initiating special capacity building programmes for rural women, young farmers and smallholders and mainstreaming HRD issue in governmental planning and programmes, and accordingly crafting policies and implementation.
\end{abstract}

\section{Keywords}

Policy Integration; Human Resource Development; Strategy; Bangladesh; Sustainable Agriculture

*Corresponding author. 


\section{Introduction}

Bangladesh has an agrarian structure dominated by the smallholders who are heavily involved with rice farming. Agriculture is the single largest producing sector of the economy as it contributes to about $18.6 \%$ of the country's GDP and employs around half of the total labour force [1]. This sector, particularly country's rice economy has made notable progress [2] [3]. This achievement is primarily attributed to the revolution of minor irrigation (e.g., shallow tube wells) and introduction of numerous high yielding rice varieties [4]. However, overall, country's agriculture is at the crossroads [5]-[7], due to conventional farming since time immemorial, indiscriminate use of agro-chemicals, declination of natural resource and visible impacts of climate change. These constrains require calibrated policy responses to achieve farming sustainability and feed the ever-growing population. In the context of environmental uncertainty, many researchers e.g., [8]-[10] reported that human capital (e.g., adaptive capacity) development is one of the best solutions for promoting sustainable agricultural development in Bangladesh.

Majority of the rural farmers are poor, less educated and conducting subsistence farming. They partially adopt modern farming systems, integrated natural resource management (e.g., applying IPM) and environmentally sound agricultural practices such as cultivating green manures. The absence of these factors is responsible for unsustainable agricultural systems and the problems have been exacerbated by inadequate extension and training services, ineffective regulation of agro-chemicals and subsidy policies [4].

Moreover, although the development of more resource conserving practices and technologies has occurred, their utilisation and dissemination are not well embraced by farmers, expectantly [11]. This phenomenon happens not only for financial limitations but also for shortage of sufficient technical knowledge, lacking of confidence and competence. Gaunt et al. [12] found that poor knowledge of efficient practices for maintaining soil fertility has been identified as an important component of the low yields achieved by rice farmers. In the era of climate change, adjustments and adaptation of agriculture mainly require strengthening the capacity of farming communities.

Despite research on the significance of human capital in agricultural development is available [8], literature on the evaluation of policy integration of human capital development is very scarce. This study fulfils the research gap. Here, capital means farming knowledge, skills and adaptive capacity of farmers. To capture the broader gamut of development, the term "human resource development" will be used instead of "human capital development" hereafter. The purpose of this study is to evaluate the degree of policy integration of human resource development (PIHRD) in agriculture sector within the context of multi-level governance (i.e., principally refers to the interdependence of administrative levels, e.g., national, regional, district in decision making). This study suggests means to enhance HRD policy integration as well.

The remainder of this study is: after presenting a brief background of the study, the understanding of PIHRD will be elaborately discussed. Then stating research planning and methodology, the result of evaluation of policy integration will be presented according to the four administrative levels in four sections with discussion. Finally, conclusions and policy implications will be drawn.

\section{Understanding Human Resource Development Policy Integration: Environmental Policy Integration Revisited}

The term "policy integration" originally emanated from the concept of environmental policy integration (EPI) that receives a well acceptance after the publication of the "Brundtland Report" [13]. Subsequently, it was evolved through the "Agenda 21" [14], the European Union (EU) and the Organisation for Economic Cooperation and Development (OECD). Policy integration (PI) is better understood by borrowing answer of several questions such as how will (we) recognise it when (we) see it and how PI is "achieved and evaluated" from the concept of EPI. Simply, PI refers to integrate certain policy objectives (e.g., climate change, gender) into other policy sectors, namely energy, transport [15]-[17]. Based on Lafferty and Hovden [18], PIHRD means the incorporation of the plans, programmes and strategies of HRD into all stages of policy making in other policy sectors such as agriculture. It facilitates more rational policy making, in that human (farmers) resource development is perceived as a vital factor for minimising environmental, economical, social and climate change problems as well as promoting sustainable agricultural development. Precisely, the whole point of PIHRD is to treat farmers' capacity development is an important instrument for tackling farming problems as well as achieving overarching societal objectives-sustainable development. 
The main objective of PIHRD is to ensure that the agricultural sector covered by the policy area is able to grow crop production sustainably (by improving knowledge, skills, attitude and capacities of growers to promote integrated management of natural resource, nutrients, pests and diseases; adopt climate-smart practices and foster farm mechanisation) even within the circumstances of a changing environment. It has been reported in key documents [e.g., Sixth Five-Year Plan (FY 2011-15)] that there is a political commitment to integrate HRD policy objectives into other policies and this should be reflected at the policy strategies and at the level of instruments such as laws, taxes, support schemes and information material by which the strategies are implemented. For example, if HRD is integrated into agricultural policies, this should be reflected in the plan, programmes and strategies of this sector and ultimately in the exposure of farmers.

Policy integration (PI) is two types, namely horizontal and vertical policy integration. Adopting definition from the study of Lafferty and Hovden [18], horizontal policy integration (HPI) of HRD refers to cross-sectoral measures and procedures by the government or some governmental body, carried out to comprehensively integrate HRD plans, programmes and strategies into public policies. Typical means include country's sustainable development strategy, climate change strategy and integration of HRD programmes in the preparation and adoption of new regulations and the annual state budget. In the same way, vertical policy integration (VPI) of HRD means the integration of plans, programmes and strategies of HRD into specific sector-agriculture. It includes sector-specific strategies and decisions made at the ministerial level as well as HRD integration into strategies, measure and actions taken by the different agencies under the supervision of a ministry.

\section{Research Planning}

An evaluation of horizontal and vertical policy integration of HRD will be conducted within the context of multi-level governance [19]. This evaluation will be supplemented by the case studies research at the Sub-district and Union level, which are the second lowest and the lowest tier of administrative level of the government of Bangladesh, respectively. Table 1 presents the research planning for evaluating PIHRD in agricultural sector.

\section{Research Methods}

This study employs three research methods: policy documents review, key informant interview and case study research. Policy instruments review (see the result section) was accomplished following the established criteria developed by researchers [20] [21]. Name of criteria and questions against each criterion were presented in Table 2. Key informants were academicians, extension workers, policy makers, local leaders, researchers and farmers. Case study, a method of study in depth rather than breadth, explored detailed information of plans, programmes and strategies of HRD at the sub-district and union level Agricultural Extension Office. A case study research is important form of qualitative analysis that involves careful and complete observation of a person/social unit/institution [22]. This method is not beyond shortcomings, for instance, the findings cannot be generalising to other people with similar issues and problems. However, careful case selection, formulating a set of empirical questions and minimising the biasness in data gathering can be produced good research insights for discussion.

\section{Study Area}

It is mentioned earlier that the study will be conducted at the national, regional, sub-district and union level. For the regional level study, the coastal zone of Bangladesh is selected and a number policies and strategies for coastal zone development were critically analysed. For the case of regional level study, the coastal zone was selected for two reasons: substantial parts (32\% of the area and $28 \%$ of the population of Bangladesh) of the country are considered as the coastal zone and paying due attention to the government's strategy as coastal zone declared as an "exclusive economic zone" [23]. Case studies were conducted to sub-districts, namely Pirganj and Dinajpur Sadar that represent irrigated and rainfed rice growing ecosystems. These sub-districts were selected employing simple random sampling method. Initially, all sub-districts were divided according to the ecosystem then applied this sampling method. It is better to mentioning here that agrarian system in Bangladesh is largely dominated by rice farming. For key informant interview, farmers, extension workers [Sub-Assistance Agriculture Officer (SAAO)] and local leaders were selected at the union level. Brief socio-economic and biophysical descriptions of these Sub-districts are presented in Table 3. 
Table 1. Planning for evaluating PIHRD in agricultural sector across the administrative levels.

\begin{tabular}{|c|c|c|}
\hline Tiers of PI & Governance Level & Example of reviewing document \\
\hline HPI & National & $\begin{array}{l}\text { National Sustainable Development Strategy 2008; Climate Change Strategy and } \\
\text { Action Plans } 2009 .\end{array}$ \\
\hline VPI & National & $\begin{array}{l}\text { National Agriculture Policy 1999; National Agriculture Extension Policy 2012; } \\
\text { National IPM Policy } 2002 .\end{array}$ \\
\hline HPI & Regional & $\begin{array}{l}\text { Coastal Zone Policy 2005; Coastal Development Strategy } 2006 \text { (Emphasis will be on } \\
\text { the coastal agriculture). }\end{array}$ \\
\hline VPI & $\begin{array}{l}\text { Sub-district/ } \\
\text { Union }\end{array}$ & $\begin{array}{l}\text { Two case studies will be conducted in areas that represent irrigated and rainfed rice } \\
\text { growing ecosystem. }\end{array}$ \\
\hline
\end{tabular}

Note: HPI and VPI refer to horizontal and vertical policy integration, respectively. "Agriculture in Bangladesh is highly dominated by rice farming.

Table 2. Criteria and its question uses in evaluating policy integration.

\begin{tabular}{|c|c|}
\hline Criterion & Key question \\
\hline Inclusion & To what extent policy instrument are directly and indirectly covered plans, programmes and strategies of HRD? \\
\hline Consistency & $\begin{array}{l}\text { Is there a consistency between the overall aim* of HRD and policy instrument? Is instrument positive for or laid } \\
\text { emphasis on plans, programmes and strategies of HRD? }\end{array}$ \\
\hline Weighting & Has the issue of HRD compared to other policy aims been addressed significantly? \\
\hline Reporting & $\begin{array}{l}\text { Are there clearly stated evaluation and reporting requirements for HRD (including deadlines) ex-ante and have } \\
\text { such evaluations for reporting happened ex-post? Have indicators been defined, followed up and used? }\end{array}$ \\
\hline Resources & $\begin{array}{l}\text { Are internal as well as external resources for HRD available and used or are there any indications for arranging } \\
\text { fund for HRD programmes? }\end{array}$ \\
\hline
\end{tabular}

*Promoting sustainable agricultural development is the main aim.

Table 3. Socio-economic and bio-physical information of the case studies area.

\begin{tabular}{|c|c|c|}
\hline Items & Pirganj, Thakurgoan & Dinajpur Sadar \\
\hline Location & $25.85^{\circ} \mathrm{N}-88.37^{\circ} \mathrm{E}$ & $25.63^{\circ} \mathrm{N}-88.65^{\circ} \mathrm{E}$ \\
\hline Farmers type ${ }^{*}(\%)$ & $\begin{array}{l}\text { Small-75 } \\
\text { Medium-21 } \\
\text { Large-4 }\end{array}$ & $\begin{array}{l}\text { Small—89 } \\
\text { Medium—9 } \\
\text { Large-2 }\end{array}$ \\
\hline Area based on soil type (ha) & $\begin{array}{c}\text { Sandy-102 } \\
\text { Sandy loam-8540 } \\
\text { Loamy soil-12230 } \\
\text { Clay-196 }\end{array}$ & $\begin{array}{c}\text { Sandy-175 } \\
\text { Sandy loam-15,853 } \\
\text { Loamy soil-19,255 } \\
\text { Clay-205 }\end{array}$ \\
\hline Cropping intensity (\%) & 225 & 270 \\
\hline Area based on land type (\%) & $\begin{array}{l}\text { High land-26 } \\
\text { Medium high land-43 } \\
\text { Medium low land-26 } \\
\text { Low land-5 }\end{array}$ & $\begin{array}{l}\text { High land-24 } \\
\text { Medium high land-51 } \\
\text { Medium low land—20 } \\
\text { Low land-5 }\end{array}$ \\
\hline Major crop & Rice (Boro, Aman) Wheat, Jute, Maize & $\begin{array}{c}\text { Rice (Aman, Boro, Aus) Wheat, Maize, Jute, } \\
\text { Vegetables }\end{array}$ \\
\hline
\end{tabular}

Source: Concerned Agricultural Office. "The amount of landless and marginal farmers is merged with small farmer type. Note: Aus, Aman and Boro refer to direct seeded or transplanted rice in pre-monsoon season, transplanted rice in monsoon and irrigated rice in dry season, respectively.

\section{Results and Discussion}

\subsection{Horizontal Policy Integration at the National Level ${ }^{1}$}

As mentioned earlier, this type of policy integration can be measured through analysing cross-sectoral policy instruments. Table 4 shows that HRD succinctly integrated in the major strategies, for example, National Sustainable Development Strategy (NSDS) 2008 and National Strategy for Accelerated Poverty Reduction (NSAPR) 2012 have included programmes on human capital development (through farmer's field school) to enhance

${ }^{1}$ For overall planning, cross-sectoral strategies have a direct contribution to all sectors including agriculture. For example, the Sixth Five-Year Plan (FY 2011-15) provides an inclusive development plan for agricultural sector. That is why, although this study deals about policy integration in agricultural sector, cross-sectoral measures were used in evaluating horizontal policy integration. 
Table 4. Horizontal policy integration of HRD in cross-sectoral policy instruments.

\begin{tabular}{|c|c|c|c|c|c|}
\hline Policy instrument & Inclusion & Consistency & Weighting & Reporting & Resources \\
\hline $\begin{array}{l}\text { National } \\
\text { Sustainable } \\
\text { Development } \\
\text { Strategy } 2008\end{array}$ & $\begin{array}{l}\text { Explicitly as HRD } \\
\text { is one of the } \\
\text { cross-cutting areas } \\
\text { of three. }\end{array}$ & $\begin{array}{l}\text { Highly consistent } \\
\text { with the vision of } \\
\text { this strategy. }\end{array}$ & $\begin{array}{l}\text { Indicating as a key } \\
\text { issue for } \\
\text { implementing govt. } \\
\text { strategies. }\end{array}$ & $\begin{array}{l}\text { Provision of monitoring } \\
\text { and evaluation using } \\
\text { indicator, e.g. } \\
\text { empowerment of women. }\end{array}$ & $\begin{array}{l}\text { Lacking of resources } \\
\text { including financial, } \\
\text { infrastructural and } \\
\text { technological. }\end{array}$ \\
\hline $\begin{array}{l}\text { Bangladesh } \\
\text { Climate Change } \\
\text { Strategy and } \\
\text { Action Plan } 2009\end{array}$ & $\begin{array}{l}\text { Indirectly as a } \\
\text { programme entitled } \\
\text { "strengthening } \\
\text { human resource } \\
\text { capacity”. }\end{array}$ & $\begin{array}{l}\text { Fairly since it } \\
\text { primarily addresses } \\
\text { adaptation and } \\
\text { mitigation. }\end{array}$ & $\begin{array}{l}\text { Insignificantly rather } \\
\text { put emphasis on } \\
\text { facilitating govt. } \\
\text { agencies, private } \\
\text { sector, etc. }\end{array}$ & $\begin{array}{l}\text { Implicitly formulates } \\
\text { implementing action } \\
\text { plans with several } \\
\text { themes and programmes. }\end{array}$ & $\begin{array}{l}\text { Indication of the } \\
\text { mobilisation and } \\
\text { international } \\
\text { provision of adequate } \\
\text { finance. }\end{array}$ \\
\hline $\begin{array}{l}\text { National Strategy } \\
\text { for Accelerated } \\
\text { Poverty Reduction } \\
\text { II } 2012\end{array}$ & $\begin{array}{l}\text { Explicitly. It reports } \\
\text { HRD is an effective } \\
\text { tool for mitigating } \\
\text { income poverty. }\end{array}$ & $\begin{array}{l}\text { Highly consistent } \\
\text { and lays particular } \\
\text { emphasis on } \\
\text { people's access to } \\
\text { information. }\end{array}$ & $\begin{array}{l}\text { Significantly } \\
\text { addresses formal and } \\
\text { non-formal education; } \\
\text { i.e., demand-led } \\
\text { education, adult } \\
\text { learning. }\end{array}$ & $\begin{array}{l}\text { Clearly articulates with } \\
\text { institutional strategy of } \\
\text { monitoring (M) and } \\
\text { evaluation (E) and } \\
\text { indicators for M\&E. }\end{array}$ & $\begin{array}{l}\text { Shortage of resources, } \\
\text { however, govt. } \\
\text { proposes other } \\
\text { strategies, e.g. } \\
\text { promoting good } \\
\text { governance. }\end{array}$ \\
\hline $\begin{array}{l}\text { National Plan for } \\
\text { Disaster } \\
\text { Management } 2010\end{array}$ & $\begin{array}{l}\text { Inexplicitly and lays } \\
\text { emphasis on } \\
\text { capacity } \\
\text { development, } \\
\text { providing } \\
\text { information, etc. }\end{array}$ & $\begin{array}{l}\text { Indirectly, e.g. } \\
\text { empowering local } \\
\text { communities and } \\
\text { infrastructure. }\end{array}$ & $\begin{array}{l}\text { Addressing local } \\
\text { people's resilience; } \\
\text { i.e., the capacity to } \\
\text { recover from } \\
\text { difficulty. }\end{array}$ & $\begin{array}{l}\text { Not precisely but reports } \\
\text { to establish institutional } \\
\text { accountability in } \\
\text { implementing plan. }\end{array}$ & $\begin{array}{l}\text { Facing several } \\
\text { challenges such as } \\
\text { poverty and climate } \\
\text { change impacts. }\end{array}$ \\
\hline $\begin{array}{l}\text { National } \\
\text { Biodiversity } \\
\text { Strategy and } \\
\text { Action Plan } 2005\end{array}$ & $\begin{array}{l}\text { Indirectly by } \\
\text { promoting } \\
\text { traditional } \\
\text { knowledge to } \\
\text { conserve natural } \\
\text { resources. }\end{array}$ & $\begin{array}{l}\text { Implicitly } \\
\text { consistent with the } \\
\text { broader aims of } \\
\text { HRD. }\end{array}$ & $\begin{array}{l}\text { Inadequately } \\
\text { addresses the issue of } \\
\text { grower's human } \\
\text { capital development } \\
\text { for conserving } \\
\text { biodiversity. }\end{array}$ & $\begin{array}{l}\text { Coordination and } \\
\text { integration problems } \\
\text { between agencies. Laws } \\
\text { and policies are largely } \\
\text { ineffective. }\end{array}$ & $\begin{array}{l}\text { No concrete financial } \\
\text { guidelines and } \\
\text { recognises the } \\
\text { shortage of money is } \\
\text { a critical challenge to } \\
\text { implement. }\end{array}$ \\
\hline $\begin{array}{l}\text { Sixth five year } \\
\text { plan FY 2011-15 }\end{array}$ & $\begin{array}{l}\text { Directly as a major } \\
\text { objective is to } \\
\text { promote sustainable } \\
\text { human } \\
\text { development. }\end{array}$ & $\begin{array}{l}\text { Consistent as states } \\
\text { human capital is “a } \\
\text { pivotal } \\
\text { development } \\
\text { instrument”. }\end{array}$ & $\begin{array}{l}\text { Properly presents and } \\
\text { states HRD is a } \\
\text { golden key for a } \\
\text { knowledge-based } \\
\text { economy. }\end{array}$ & $\begin{array}{l}\text { Setting targets and } \\
\text { strategies, but few about } \\
\text { informal education, e.g. } \\
\text { IPM training. }\end{array}$ & $\begin{array}{l}\text { Challenging in } \\
\text { resources } \\
\text { management and } \\
\text { resource depends on } \\
\text { donor-based supports. }\end{array}$ \\
\hline
\end{tabular}

farmer's skills and capacities for better land and water management. NSDS reports that vital issues in this strategy are "improvement of quality of human resources and better management” with a view to obtain agricultural and rural development as well as sustain economic growth [24], since human lives and livelihood are intricately intertwined with nature. Likewise, climate change strategy and NSAPR states HRD as an adaptive strategy for avoiding climate vulnerabilities and a key tool for poverty alleviation, respectively. However, the Sixth Five Year Plan (FY 2011-15) not only includes HRD as a major objective but also figure out a fully-fledged strategy to achieve it [25].

Integrating policy objectives, to some extent inclusion is mandatory. Bangladesh is an agrarian country that dominates by smallholder (about 81\%). The typical features of majority farmers are poor, less educated (no education or up to primary school) and largely disadvantaged in terms of receiving public services, particularly agricultural extension services [7]. However, government has been implementing numerous projects through several agencies such as Department of Agricultural Extension, Bangladesh Rural Development Board, NGOs and partner organisations, e.g., FAO, UNDP to uplifting the socio-economic condition of farmers. Paying due attention on the challenges (e.g., poverty alleviation, minimising environmental degradation), an overriding objectives has been embedded in policy instruments to improve farmer's skills and capacity building so that they can play a vital role in increasing agricultural productivity and profitability as well as fostering sustainable socio-economic development. Moreover, other initiatives on addressing gender equity, empowering of women and rural youth through improving technical know-how-based education, training and research illuminates the inclusion of HRD in different strategies.

In terms of consistency between the broad aims of HRD (promoting sustainable agriculture as well as socioeconomic development) and the respective strategy, a mixed picture was observed (Table 4). Overall objectives of NSDS 2008 are fairly consistent with the objectives of HRD. However, an inexplicit harmony is reported 
between the aims of National Plan for Disaster Management and Bio-diversity Strategy and Action Plan and HRD. Disaster management plan lays emphasis on management of both risks and consequences of disaster that allude to strengthen human, financial and social capital. This plan identifies developing and implementing disaster management training, education, research and awareness programmes as the priority areas for action [26]. Besides, biodiversity strategy discusses importantly the sustainable use and sharing the benefits of biodiversity [27]. It can be improved and enhanced through the conserving and restoring the biodiversity for well-being of the present and future generations, and certainly it needs a greater awareness and knowledge of conservation and management [28] [29].

The issue of HRD significantly addresses in NSSD 2008 and Sixth Five-Year plan (FY 2011-15), as this plan point out that HRD is a "golden key" for a knowledge-based economy and competitiveness [25]. However, in biodiversity and climate change strategy it receives less priority in terms of setting necessary plans and programmes (Table 4). The provision of reporting as well as impact assessment or evaluation (e.g., environmental impact assessment) of most of the strategies are not structured and loosely discussed, for example, National Disaster Management Plan does not have any indicators or indicator systems [30] [31] so that the progress can be evaluated. Similarly, these shortcomings are reported in biodiversity as well as climate change strategy. Despite the fact that environmental impact assessment (EIA) rules were enacted since more than two decades back in this country, practically it application is non-existent in most of the sectors including agriculture, and implementation of EIA was largely dependent on the requirements of donor agencies [32]. However, the Sixth Five-Year Plan (2011-2015) stresses that the significance of EIA and drafting of EIA guidelines for all sectors under the Environment Conservation Act 1995 [25].

In terms of arranging financial resources, PIHRD is in the worst situation. All most all strategies (e.g., National Biodiversity Strategy 2005) do not provide funding information on how they implement the documented plans and programmes (Table 4). This financial shortage indicates an adverse situation where programmes implementation is difficult at the field level. The results are consistent with others report e.g. [25], as the government recognizes resource problem is one of the major challenges of this country. Bangladesh is still a low income country with widespread poverty; estimating $17.6 \%$ people live below the national poverty line of US \$2 per day [33]. In fact, this country is experiencing "resource crunch" as a result of rapid population growth.

\subsection{Vertical Policy Integration at the National Level}

Vertical policy integration is assessed in agricultural sector that is reflected by its several policies, strategies and instruments including National Agriculture Policy (NAP) 2010, National IPM Policy and others. The first criteria of policy integration is "inclusion" that is clearly reflected in all policies (Table 5). For instance, National Agricultural Extension Policy 1996 reported a concrete plan for human capital development by providing information, services and training. Similarly, IPM policy has taken a big vision to enhance farmer's knowledge, skills and capacities to use and disseminate IPM technologies across the farmers (i.e., small medium and large) and country.

Around half of rice growers produce rice by traditional way and to some extent this approach hampers in producing maximum yield. Some researchers argue that the total rice production reached a plateau and the trend is gradually declining [34] [35]. A new strategy and new approach with appropriate technological breakthrough is now a reality to feed the ever increasing population. Currently, average per hectare output of rice remains measurably lower than India and about half that of China [36]. It is logistically realistic to develop farmer's skill, capacities and competencies to adopt modern ecological farming, climate-smart technologies and diversified and integrated food-energy systems as well as to promote the sustainable intensification of crop production at different levels.

The surveyed policies (see Table 5) are marginally consistent with the aim of HRD such as irrigation policy merely reported to be improved farmer's capacity for small scale water management without mentioning concrete initiatives (e.g., target, institutional setup). Likewise, there is no useful information on farmer's human capital development in the visionary report of Bangladesh Agricultural Research Council (BARC) entitled "Agricultural Research Vision 2030 and Beyond”. Although this report elaborately described several sub-sectors, namely "land and soil resource management" and "farm machinery, irrigation and water management and post-harvest technology" with tentative future planning for research priorities. It does not clarify how farmers will adopt the fresh approaches, in the context of farmers with limited technical knowledge and weaker extension systems. 
Table 5. Vertical policy integration of HRD in agricultural sector at the national level.

\begin{tabular}{|c|c|c|c|c|c|}
\hline Policy instrument & Inclusion & Consistency & Weighting & Reporting & Resources \\
\hline $\begin{array}{l}\text { National Agriculture } \\
\text { Policy (NAP) } 2010\end{array}$ & $\begin{array}{l}\text { HRD and management } \\
\text { is a significant aspect. } \\
\text { BARC is instructed } \\
\text { for its facilitation and } \\
\text { patronisation. }\end{array}$ & $\begin{array}{l}\text { The aim of } \\
\text { "sustainable growth } \\
\text { of agriculture" } \\
\text { indicates a fair } \\
\text { consistency. }\end{array}$ & $\begin{array}{l}\text { Fairly discusses and } \\
\text { proposes strategy } \\
\text { for HRD through } \\
\text { public private } \\
\text { partnership. }\end{array}$ & $\begin{array}{l}\text { Monitoring and } \\
\text { evaluation (M\&E) is } \\
\text { weak and no specific } \\
\text { target and indicator } \\
\text { of M\&E is provided. }\end{array}$ & $\begin{array}{l}\text { A block allocation for } \\
\text { HRD and } \\
\text { gender-based training } \\
\text { is mentioned. }\end{array}$ \\
\hline $\begin{array}{l}\text { National } \\
\text { Agricultural } \\
\text { Extension Policy } \\
1996\end{array}$ & $\begin{array}{l}\text { Explicitly. Providing } \\
\text { of information, advice } \\
\text { and training to farmers } \\
\text { is the main strategy of } \\
\text { this policy. }\end{array}$ & $\begin{array}{l}\text { Coherently illustrates } \\
\text { integrated extension } \\
\text { support to farmers to } \\
\text { promote SA } \\
\text { development. }\end{array}$ & $\begin{array}{l}\text { HRD states } \\
\text { importantly and } \\
\text { says to promote by } \\
\text { training and } \\
\text { providing logistic } \\
\text { supports. }\end{array}$ & $\begin{array}{l}\text { Presenting } \\
\text { fragmented } \\
\text { information on } \\
\text { evaluation and } \\
\text { reporting. }\end{array}$ & $\begin{array}{l}\text { Stating a good plan } \\
\text { for implementation } \\
\text { but lacking of } \\
\text { information on } \\
\text { resources. }\end{array}$ \\
\hline $\begin{array}{l}\text { Small Scale } \\
\text { Irrigation Policy } \\
2012\end{array}$ & $\begin{array}{l}\text { Fairly as purpose of } \\
\text { the policy is to reduce } \\
\text { water loss and } \\
\text { promote efficient } \\
\text { water management by } \\
\text { improving skills. }\end{array}$ & $\begin{array}{l}\text { Planning of } \\
\text { sustainable irrigation } \\
\text { system indicates a } \\
\text { marginal consistent } \\
\text { with the aim of HRD. }\end{array}$ & $\begin{array}{l}\text { Relatively } \\
\text { insignificantly } \\
\text { reported. }\end{array}$ & $\begin{array}{l}\text { Stating inadequate } \\
\text { information, e.g. } \\
\text { ambiguously reports } \\
\text { integration between } \\
\text { the GOs, POs and } \\
\text { NGOs will be } \\
\text { formed. }\end{array}$ & $\begin{array}{l}\text { Empowering local } \\
\text { level committees and } \\
\text { practicing multilevel } \\
\text { governance is a good } \\
\text { sign of resource } \\
\text { management. }\end{array}$ \\
\hline $\begin{array}{l}\text { National Integrated } \\
\text { Pest Management } \\
\text { (IPM) Policy } 2002\end{array}$ & $\begin{array}{l}\text { Explicitly addresses. } \\
\text { The objective of IPM } \\
\text { policy is "to enable } \\
\text { farmers to produce } \\
\text { healthy crops". }\end{array}$ & $\begin{array}{l}\text { It lays emphasis on } \\
\text { grower's self-reliance } \\
\text { and empowerment, } \\
\text { establishing FFSs. }\end{array}$ & $\begin{array}{l}\text { This policy states } \\
\text { "HRD as the core of } \\
\text { IPM"-indicates a } \\
\text { good gesture of } \\
\text { significance. }\end{array}$ & $\begin{array}{l}\text { Monitoring and } \\
\text { evaluation of and } \\
\text { follow-up to IPM } \\
\text { activities are } \\
\text { reported. }\end{array}$ & $\begin{array}{l}\text { Govt. has funding } \\
\text { plans as well as } \\
\text { depends on donor } \\
\text { funds for the } \\
\text { continuation of IPM } \\
\text { activities. }\end{array}$ \\
\hline $\begin{array}{l}\text { Agricultural } \\
\text { Research Vision } \\
2030 \text { and Beyond }\end{array}$ & $\begin{array}{l}\text { Indirectly, e.g. } \\
\text { ICT-based human } \\
\text { resource development. }\end{array}$ & $\begin{array}{l}\text { There is no explicit } \\
\text { consistency. }\end{array}$ & $\begin{array}{l}\text { Insignificantly } \\
\text { addresses. }\end{array}$ & $\begin{array}{l}\text { Inadequate } \\
\text { information } \\
\text { provides. }\end{array}$ & $\begin{array}{l}\text { Proposes several } \\
\text { funding sources and } \\
\text { not specific for HRD. }\end{array}$ \\
\hline
\end{tabular}

Notes: HRD means human resource development; BARC refers to Bangladesh Agricultural Research Council; SA means sustainable agriculture, GO and POs mean Government and private organisation, respectively, FFS means farmers' field school.

Most of polices insignificantly addresses HRD issue except IPM policy which stated HRD as a "core issue" for pest and disease management. National Agriculture Policy 2010 fairly mentioned the significance of knowledge and skills development but lacking of necessary information on how to build and strengthen public private partnership for adoption and dissemination agricultural innovation [37]. Similar to horizontal policy integration in cross-sectoral policy measures, the reporting system (ex-ante evaluation and follow up activities) and arrangement of funding is rather weak, in terms of providing concrete guidelines.

Monitoring, evaluation and reporting system in agriculture sector is rather weak as ever due to the weaker institutional system [38]. Similarly, no cooperation and coordination among different administrative tiers have observed. In agriculture, ex-ante or ex-post evaluation is hardly applied before project evaluation; for instance, National Agricultural Extension Policy 1996, theoretically proposes a statement for applying EIA to monitor the environmental impacts of agricultural practices. It is elucidated in discussion that majority of agricultural institutions suffering different extent of shortage of manpower and physical facilities due to the shrinkage of development budget. This finding is consistent with the results of other research, e.g. [38].

\subsection{Vertical Policy Integration of HRD at the Regional Level}

This evaluation of vertical policy integration of HRD at the regional level was done in three policy instruments (Table 6) of coastal zone development and particular emphasis was given on the coastal farming and natural resource management. The results show that all three instruments are included HRD as an important issue and consistent with the broad objective of HRD. Specifically, Coastal Zone Policy 2005 states succinct information on farmer's capital development through creating awareness, encouraging participation in land management and addressing gender issues. In addition, HRD receives a significant attention in the Coastal Zone Policy 2005. Overall, resources and reporting system are inadequately discussed. The Coastal Development Strategy 2006 provides a good picture of financial resource management and National Programme of Action for the Protection of the Marine Environment 2007 reports poor information on monitoring and evaluation. 
Table 6. Vertical policy integration of HRD at the regional level (the emphasis is on the coastal farming and natural resource management).

\begin{tabular}{|c|c|c|c|c|c|}
\hline Policy instrument & Inclusion & Consistency & Weighting & Reporting & Resources \\
\hline $\begin{array}{l}\text { Coastal Zone Policy } \\
\text { (CZPo) } 2005\end{array}$ & $\begin{array}{l}\text { Improving people's } \\
\text { capacity by } \\
\text { creating awareness, } \\
\text { ensuring } \\
\text { participation and } \\
\text { enhancing gender } \\
\text { equity. }\end{array}$ & $\begin{array}{l}\text { Having harmonised } \\
\text { aims to uplift } \\
\text { socio-economic } \\
\text { developments as well } \\
\text { as contribute national } \\
\text { development. }\end{array}$ & $\begin{array}{l}\text { Receives an } \\
\text { important attention } \\
\text { under the heading of } \\
\text { "empowerment of } \\
\text { communities". }\end{array}$ & $\begin{array}{l}\text { No guidelines for } \\
\text { monitoring and } \\
\text { assessing } \\
\text { performances are } \\
\text { provided. }\end{array}$ & $\begin{array}{l}\text { No information } \\
\text { reported on funding } \\
\text { rather stated that } \\
\text { "Coastal } \\
\text { Development } \\
\text { Strategy" will present } \\
\text { financial strategy. }\end{array}$ \\
\hline $\begin{array}{l}\text { Coastal } \\
\text { Development } \\
\text { Strategy (CDS) } 2006\end{array}$ & $\begin{array}{l}\text { Empowering } \\
\text { people's through } \\
\text { knowledge } \\
\text { management as } \\
\text { well as sustainable } \\
\text { livelihood } \\
\text { approach. }\end{array}$ & $\begin{array}{l}\text { Observing coherent } \\
\text { features as proper } \\
\text { management of } \\
\text { natural resources, } \\
\text { e.g., } \\
\text { agro-biodiversity. }\end{array}$ & $\begin{array}{l}\text { Discuss as a } \\
\text { significant } \\
\text { programme } \\
\text { "investment in } \\
\text { human development” } \\
\text { for adaptive farming, } \\
\text { e.g., soil-less and } \\
\text { bio-saline agriculture. }\end{array}$ & $\begin{array}{l}\text { Formulates three } \\
\text { aspects of governance, } \\
\text { e.g., legal frameworks } \\
\text { that states to perform } \\
\text { monitoring and } \\
\text { assessment with a set } \\
\text { of inputs, outputs and } \\
\text { outcome indicators. }\end{array}$ & $\begin{array}{l}\text { Provides concrete } \\
\text { five financial } \\
\text { strategies, e.g. public } \\
\text { and private } \\
\text { investments as well } \\
\text { as said to facilitate } \\
\text { small and medium } \\
\text { enterprises by NGOs. }\end{array}$ \\
\hline $\begin{array}{l}\text { National Programme } \\
\text { of Action (NPA) for } \\
\text { the Protection of the } \\
\text { Marine (Coastal) } \\
\text { Environment } 2007\end{array}$ & $\begin{array}{l}\text { Includes as a major } \\
\text { strategy entitled } \\
\text { "promotion of } \\
\text { awareness and } \\
\text { capacity building”. }\end{array}$ & $\begin{array}{l}\text { Diversified coastal } \\
\text { cropping systems are } \\
\text { stated as an important } \\
\text { approach for } \\
\text { sustainable } \\
\text { livelihood. Judicious } \\
\text { use of agro-chemicals } \\
\text { is crucial strategy of } \\
\text { NPA. }\end{array}$ & $\begin{array}{l}\text { Significantly } \\
\text { discussed the key } \\
\text { issues of HRD, e.g., } \\
\text { training, awareness, } \\
\text { research and } \\
\text { monitoring. }\end{array}$ & $\begin{array}{l}\text { Reviewing and } \\
\text { monitoring is done by } \\
\text { a steering committee, } \\
\text { consisting of } 18 \\
\text { members. Little } \\
\text { information on ex-ante } \\
\text { or ex-post evaluation } \\
\text { and particularly on } \\
\text { indicators. }\end{array}$ & $\begin{array}{l}\text { Inadequate funding } \\
\text { information. The } \\
\text { UNEP and Global } \\
\text { Programme of Action } \\
\text { partially provide } \\
\text { project based } \\
\text { funding. }\end{array}$ \\
\hline
\end{tabular}

The coastal zone is highly vulnerable due to over exploitation of natural resources (e.g., hill cutting), increasing unplanned urbanization, polluting and declining land and water resources and visible climate change impacts [23]. However, it has huge potentials and opportunities and some unique ecosystems. Justifiably, this zone can make a substantial contribution to achieve the national goals of accelerated poverty reduction and sustainable economic growth by harnessing and exploiting its opportunities in a systematic and coordinated way. Thus, there are valid reasons for empowering the local communities through knowledge management and improving livelihood condition. However, other issues need to be addressed such as monitoring, evaluation and reporting of development activities with an accountable and manageable financial system where government has to play a proactive role through coordinating and organising other stakeholders including NGOs, multi-national companies, donor agencies and development partners.

\subsection{Vertical Policy Integration at the Sub-District Level}

Table 7 presents a realistic picture of HRD initiatives at the sub-district level. It is not wise to draw general conclusion from the case study research. The results indicate that shortage of funding is a major hindrance of surveyed agricultural office for initiating and conducting HRD programmes as well as of farmers to adopt new technologies. The number of officers and famers is another big challenge for providing services to all growers (ratio of farmers and officers is 900:1). Moreover, besides their own duties and responsibilities, agricultural extension officers serve other governmental duties (e.g., taking public examination) that create extra burden for them which was revealed in discussion. The results indicate that although the issue of HRD is documented adequately in different policies and strategies, at the field level, it is not implementing properly.

The result of case studies provides a good insight for discussion and inputs for policy implication. First of all, case study findings indicates an inefficient extension system as well as a weaker HRD policy integration at the sub-district level, in terms of implementing human capital development programmes which are largely dependent on the availability of government project. Currently, sub-district agricultural office does not have development budget. Consulting with secondary data and discussion with stakeholders revealed that a negligible percentage of farmers receive training (although trainees pointed out several limitations of the training programmes), poor diversification of extension activities that looses farmers interest and confidence on activities, farmers face numerous problems as well as government also encounters several challenges (Table 7). Moreover, 
Table 7. Summary of the case study results.

\begin{tabular}{|c|c|c|}
\hline Name of item & Pirganj Sub-district & Dinajpur Sadar Sub-district \\
\hline Ongoing project ${ }^{1}$ & Agricultural technology transfer & $\begin{array}{l}\text { Construction of Rubber Dams in Small and Medium } \\
\text { Rivers and Agricultural technology transfer }\end{array}$ \\
\hline$\%$ of farmers who received training ${ }^{2}$ & 1 & 1.9 \\
\hline$\%$ of farmers who received farm publications ${ }^{3}$ & 21 & 28 \\
\hline Establishment of crops demonstration plots & 19 & 23 \\
\hline Field days and farmers rally & No & 3 \\
\hline$\%$ of farmers who received subsidy & 85 & 87 \\
\hline$\%$ of farmers who received inputs assistance & 0.5 & $0.5-1$ \\
\hline$\%$ of officer who received training & 90 & 100 \\
\hline Main content of training programmes & $\begin{array}{l}\text { IPM, crop diversification, seed } \\
\text { bed preparation and using LLC, } \\
\text { seed production }\end{array}$ & $\begin{array}{l}\text { Water management, compost preparation, pulse crop } \\
\text { cultivation, seed production, etc. }\end{array}$ \\
\hline $\begin{array}{l}\text { Structured cooperation and coordination } \\
\text { among stakeholders }{ }^{4}\end{array}$ & No & Currently no \\
\hline Problems (farmers) & \multicolumn{2}{|c|}{$\begin{array}{l}\text { Farmer's financial inability to apply technology for which received training, biases in } \\
\text { trainee selection, insufficient training allowance, disinterest in adopting new technologies } \\
\text { due to lack of knowledge, skills and capacities. }\end{array}$} \\
\hline Challenges (government) & \multicolumn{2}{|c|}{$\begin{array}{l}\text { Lack of funding/project for training/extension activities, shortage of modern training } \\
\text { equipments for empirical learning, lack of highly qualified trainers, lack of coordination } \\
\text { between service provider agencies, lack of working facilities. }\end{array}$} \\
\hline
\end{tabular}

Source: Respective agricultural office and key informant interview. Note: LLC means Leaf colour chart. ${ }^{1}$ Most of the HRD programmes depend on the availability of project as there is no development fund for these programmes. ${ }^{2}$ Generally, the duration of training programme are 3 to 8 hours. It is a formal way to improve farmer's skills. Besides training there are several ways to enhance farmer's knowledge, skills, attitude and innovation adoption. ${ }^{3}$ Leaflet, bulletin, folders and so on. ${ }^{4}$ Government, private and non-government organisations and farmer.

it is realised that several development works going on at the field levels, patronising by the different agencies (e.g., GOs, and NGOs). However, a strong structured coordination and cooperation can serve in a more holistic way since some farmers (e.g., large farmers) are being involved with several agencies (e.g., receiving agricultural loan from the government banks and NGOs and producing seeds as a delegate of contract farmer of the government) and marginal farmers as well as share tenants cannot manage access to such services.

\subsection{Conclusions and Implications}

The issue of policy integration of particular objective such as environment, regional development, climate change attracts scholarly interest as well as receives adequate political backing. This study evaluates policy integration of human resource development (HRD) in agricultural sector. Conducting a critical review of policy documents, key informant interview of stakeholders and two case studies at the field level, this study has drawn the following conclusions: 1) HRD issue has fairly included and observed consistency (between the overall aim of HRD and policies) in all policies and strategies, 2) majority of policy instruments have significantly addressed the significance of HRD and added the plans for its further development, 3) reporting, monitoring and evaluation of policies and strategies are rather weak and institutional strategies for HRD are very poor, which alludes a link of the unavailability of financial resource and 4) there is no adequate flow of resource arrangement that is mainly determined by the availability of government project.

Based on the results, the following means should be effective for improving HRD policy integration in agricultural sector: 1) providing a handsome amount of development budget at the sub-district agricultural office to develop human resources with maintaining the highest level of accountability and transference, 2) formulating coherent strategies to build a effective cooperation, coordination and participation among stakeholders to understand the whole problem of HRD and conduct inclusive capacity building programmes, 3) prioritising needbased training programmes on the basis of farmer's categories, farming ecosystems and geographical features such as land, climate, natural resources, 4) initiating special HRD programmes for rural women, young farmers and smallholders and 5) mainstreaming HRD in governmental plans, programmes and policies as well as crafting strategies according to the past experience and focusing futuristic vision. Finally, recognising the diversity of 
agro-ecological zones (30 in Bangladesh) and agricultural challenges emerging from the impact of climate change, "one-size-fits all solutions” will not work. Therefore, a range of socio-economically and technologically feasible human capacity building initiatives can play a leading role in promoting sustainable agricultural development in rice producing regions.

\section{Acknowledgements}

The authors wish to acknowledge the Long Term Research Grant "Urban Water Cycle Processes, Management and Societal Interactions: Crossing from Crisis to Sustainability” 203/PKT/6720004 that supported this study.

\section{References}

[1] BBS (Bangladesh Bureau of Statistics) (2012) Statistical Yearbook of Bangladesh. BBS Division, Ministry of Planning (MoP), Government of Bangladesh (GoB).

[2] Ahmed, R.A. (2001) Prospects of the Rice Economy in Bangladesh. The University Press, Ltd., Dhaka.

[3] Dorosh, P. (2006) Accelerating Income Growth in Rural Bangladesh. World Bank, Washington, D.C.

[4] Hossain, M. (2009) The Impact of Shallow Tube Wells and Boro Rice on Food Security in Bangladesh. IFPRI Discussion Paper 00917, IFPRI.

[5] CPD (Centre for Policy Dialogue) (2000) Bangladesh Agriculture at the Crossroads: Current Challenges. Report No. 36, Dhaka.

[6] IAASTD (International Assessment of Agricultural Knowledge, Science and Technology for Development) (2009) Global Report: Agriculture at a Crossroads. Island Press, Washington, DC.

[7] Asaduzzaman, M., Ringler, C., Thurlow, J. and Alam, S. (2010) Investing in Crop Agriculture in Bangladesh for Higher Growth and Productivity, and Adaptation to Climate Change. Bangladesh Food Security Investment Forum, Dhaka.

[8] World Bank (2005) Revitalizing the Agricultural Technology System in Bangladesh. Bangladesh Development SeriesPaper No. 7. The World Bank Office, Dhaka.

[9] Roy, R., Chan, N.W. and Rainis, R. (2014) Rice Farming Sustainability Assessment in Bangladesh. Sustainability Science, 9, 31-44. http://dx.doi.org/10.1007/s11625-013-0234-4

[10] Roy, R., Chan, N.W. and Rainis, R. (2013) Development of an Empirical Model of Sustainable Rice Farming: A Case Study from Three Rice-Growing Ecosystems in Bangladesh. American-Eurasian Journal of Agricultural \& Environmental Sciences, 13, 449-460.

[11] Pretty, J., Noble, A.D., Bossio, D., Dixon, J., Hine, R.E., Penning, R.E., De Vries, F.W.T. and Morison, J.I.L. (2006) Resource Conserving Agriculture Increases Yields Developing Countries. Environment Science and Technology, 40, 1114-1119. http://dx.doi.org/10.1021/es051670d

[12] Gaunt, J.L., Best, S.K., Sutherland, J.R., Norrish, A.J. and Robinson, P. (2003) The Researcher-Farmer Interface in Rice Wheat Systems: Moving from Agricultural Productivity to Livelihoods. In: Improving the Productivity and Sustainability of Rice-Wheat Systems: Issues and Impacts. ASA Special Publ. 65, Am. Soc. Agron., Madison.

[13] WCED (World Commission on Environment and Development) (1987) Our Common Future. Oxford University Press, Oxford.

[14] UNCED (United Nations Conference on Environment and Development) (1992) Agenda 21. United Nations, New York.

[15] Persson, A. (2005) Environmental Policy Integration: An Introduction. PINTS Background Paper. SEI, Stockholm.

[16] Mickwitz, P. and Kivimaa, P. (2007) Evaluating Policy Integration: The Case of Policies for Environmentally Friendlier Technological Innovations. Evaluation, 13, 68-86. http://dx.doi.org/10.1177/1356389007073682

[17] Jordan, A. and Lenschow, A. (2010) Environmental Policy Integration: A State of the Art Review. Environmental Policy and Governance, 20, 147-158. http://dx.doi.org/10.1002/eet.539

[18] Lafferty, W.M. and Hovden, E. (2003) Environmental Policy Integration: Towards an Analytical Framework. Environmental Politics, 12, 1-22. http://dx.doi.org/10.1080/09644010412331308254

[19] Bache, I. and Flinders, M. (2005) Themes and Issues in Multi-Level Governance. In: Bache, I. and Flinders, M., Eds., Multi-Level Governance, Oxford University Press, Oxford, 1-11.

[20] Kivimaa, P. and Mickwitz, P. (2006) The Challenge of Greening Technologies_Environmental Policy Integration in Finnish Technology Policies. Research Policy, 35, 729-744. http://dx.doi.org/10.1016/j.respol.2006.03.006 
[21] Kivimaa, P. and Mickwitz, P. (2009) Making the Climate Count-Climate Policy Integration and Coherence in Finland. Finnish Environment Institute, Helsinki.

[22] Kothari, C.R. (2004) Research Methodology—Methods and Techniques. 2nd Edition, New Age, New Delhi.

[23] WRPO (Water Resources Planning Organization) (2004) Coastal Development Strategy 2006. Ministry of Water Resources, GoB, 2006. International Publisher, New Delhi, 414.

[24] DoE (Department of Ministry) (2008) National Sustainable Development Strategy Bangladesh. Ministry of Environment and Forests, GoB.

[25] MoP (Ministry of Planning) (2011) Sixth Five-Year Plan FY2011-2015: Accelerating Growth and Reducing Poverty (Part-1 Strategic Directions and Policy Framework). Planning Commission, Government of Bangladesh (GoB).

[26] DMB (Disaster Management Bureau) (2010) National Plan for Disaster Management 2010-2015. Government of Bangladesh (GoB).

[27] MoEF (Ministry of Environment and Forests) (2005) National Biodiversity Strategy and Action Plan for Bangladesh 2005. GoB.

[28] MEA (Millennium Ecosystem Assessment) (2005) Ecosystems and Well-Being. Island Press, Washington, DC.

[29] Fubusa, Y.J. (2010) Conservation from the Bottom-Up: Human, Financial, and Natural Capital as Determinants of Resilient Livelihoods in Kigoma Rural Tanzania. Ph.D. Thesis, Utah State University.

[30] Roy, R., Chan, N.W. and Rainis, R. (2013) Development of Indicators for Sustainable Rice Farming in Bangladesh: A Case Study with Participative Multi-Stakeholder Involvement. World Applied Science Journal, 22, 672-682.

[31] Roy, R. and Chan, N.W. (2012) An Assessment of Agricultural Sustainability Indicators in Bangladesh: Review and Synthesis. Environmentalist, 32, 99-110.

[32] Momtaz, S. (2002) Environmental Impact Assessment in Bangladesh: A Critical Review. Environmental Impact Assessment Review, 22, 163-179. http://dx.doi.org/10.1016/S0195-9255(01)00106-8

[33] MoF (Ministry of Finance) (2012) Bangladesh Economic Survey 2012. Economic Adviser’s Wing, Finance Division, Ministry of Finance, Government of Bangladesh (GoB).

[34] Hazell, P.B.R. (2008) An Assessment of the Impact of Agricultural Research in South Asia since the Green Revolution. CGIAR Science Council Secretariat, Rome.

[35] Asaduzzaman, M. (2009) Getting Agriculture Moving Once Again: Strategic Options for Post-HYV Agriculture in Bangladesh. UK Department for International Development, Dhaka.

[36] Ziauddin, A.T.M. and Ahmmed, S. (2010) Agricultural Research: Vision 2030 and Beyond. In: A Final Report on Research Priorities in Farm Machinery, Irrigation \& Water Management and Post-Harvest Technology. BARC, Dhaka.

[37] MoA (Ministry of Agriculture) (2010) National Agricultural Policy 2010. GoB.

[38] Roy, R., Chan, N.W., Uemura, T. and Imura, H. (2013) The Vision of Agri-Environmental Sustainability in Bangladesh: How the Policies, Strategies and Institutions Delivered? Journal of Environmental Protection, 4, 40-51. http://dx.doi.org/10.4236/jep.2013.48A2006 